\title{
Cyclosporin A improves murine pregnancy outcome in abortion-prone matings: involvement of CD80/86 and CD28/CTLA-4
}

\author{
Wen-Hui Zhou ${ }^{1,3}$, Lin Dong ${ }^{1}$, Mei-Rong Du ${ }^{1}$, Xiao-Yong Zhu ${ }^{1}$ and Da-Jin $\mathrm{Li}^{1,2}$ \\ ${ }^{1}$ Laboratory for Reproductive Immunology, Hospital and Institute of Obstetrics and Gynecology, Fudan University \\ Shanghai Medical College, Shanghai 200011, China, ${ }^{2}$ Department of Obstetrics and Gynecology, The Affiliated \\ Hospital, Hainan Medical College, Haikou 570102, China and ${ }^{3}$ Department of Obstetrics and Gynecology, \\ Zhongnan Hospital of Wuhan University, Wuhan 430071, China
}

Correspondence should be addressed to D-J Li; Email: djli@shmu.edu.cn

W-H Zhou and L Dong contributed equally to this work

\begin{abstract}
Immune regulation during pregnancy is complex, and thus an optimal therapy for pregnancy complications is always a big challenge to reproductive medicine. Cyclosporin A (CsA), a potent immunosuppressant, prevents rejection of allografts by hosts, but little is known about the modulating effect of $\mathrm{CsA}$ on the materno-fetal relationship. Here, pregnant $\mathrm{CBA} / \mathrm{J}$ females mated with DBA/2 males as an abortion-prone model were administered with CsA on day 4.5 of gestation, and the pregnant CBA/J females mated with BALB/c males were established as successful pregnancy control. It was demonstrated that administration of CsA at the window of implantation significantly up-regulated the expression of CTLA-4, while down-regulating the levels of CD80, CD86, and CD28 at the materno-fetal interface in the CBA/J $\times$ DBA/2 abortion-prone matings, and the embryo resorption rate of the abortion-prone matings reduced significantly after CsA treatment, implying that modulation of costimulatory molecule expression by CsA might contribute to preventing the fetus from maternal immune attack. In addition, treatment with CsA induced enhanced growth and reduced cell apoptosis of the murine trophoblast cells. Together, these findings indicate that CsA has a beneficial effect on the materno-fetal interface in abortion-prone matings, leading to a pregnancy outcome improvement, which might provide new therapeutics for spontaneous pregnancy wastage.
\end{abstract}

Reproduction (2008) 135 385-395

\section{Introduction}

A successful pregnancy is a very complex process involving synchronized molecular and cellular events between the fetus-derived trophoblast cells and the mother-derived immune cells. After the invasion into the decidua, trophoblasts, carrying paternal antigens, are in close contact with the maternal immune cells. Amazingly, the maternal immunocompetent cells do not attack the embryo, and even cooperate with trophoblasts via the production of some cytokines and growth factors to participate in the establishment of a unique materno-fetal immune milieu that helps the fetus to survive and develop in the uterus till parturition (Saito et al. 1993, Jokhi et al. 1994a, 1994b, Saito 2000, Veenstra van Nieuwenhoven et al. 2003, Higuma-Myojo et al. 2005, Staun-Ram \& Shalev 2005). Thus, there is a subtle chorus rather than simple rivalry between the distinguished cells. Dysfunction of trophoblasts or excessive activation of maternal immunocompetent cells is highly linked with some pregnancy failures, such as abortion, pre-eclampsia, fetal growth restriction, and so on (Hustin et al. 1990, Hill et al. 1995, Yamada et al. 2003, Ball et al. 2006, Kadyrov et al. 2006). However, the immune regulation during pregnancy is intricate, and seeking an optimal therapy that gives consideration to both fetus-derived trophoblasts and mother-derived immunocompetent cells is always a big challenge to reproductive medicine.

Cyclosporin A (CsA) is a potent immunosuppressant, which has been widely used to prevent organ rejection (Sketris et al. 1995). It is well accepted that CsA can inhibit activation of $\mathrm{T}$ cells through suppressing the $\mathrm{Ca}^{2+}$ /calcineurin/calmodulin/NFAT signaling pathway that is important to the transcriptional activation for interleukin-2 (Emmel et al. 1989, Liu et al. 1992, Nelson et al. 1993). It has been found that CsA can also influence functions of other immune cells, including natural killer (NK) cells, macrophages, as well as dendritic cells (Wasowska et al. 2001, Sauma et al. 2003, Chen et al. 2004, Poggi \& Zocchi 2005). CsA even modulates the expression of two crucial costimulatory 
molecules, CD80 and CD86, which are pivotal in the induction of the alloantigen-specific tolerance (Sayegh \& Turka 1995, Jirapongsananuruk \& Leung 1999, Lee et al. 1999). The clinical application of CsA has revolutionized organ transplantation and also improved the therapeutic management of some autoimmune diseases.

Pregnancy is a major challenge to the maternal immune system because of the persistence of paternal alloantigens. Although localized mechanisms may contribute to fetal evasion from maternal immune attack, maternal alloreactive lymphocytes do exist at the materno-fetal interface (Abadia-Molina et al. 1996, Trundley \& Moffett 2004). Antigens coming from trophoblasts could activate proliferation and interferon- $\gamma$ production by uterine NK cells (van der Meer et al. 2004, 2007), suggesting that embryo has the potential to stimulate maternal lymphocytes. Over-activation and consequent attack of maternal immune cells to the fetus is postulated to be an important cause of some pregnancy complications, such as recurrent abortion and pre-eclampsia (de Groot et al. 1996, Chao et al. 1999, Laird etal. 2003, Matthiesen etal. 2005). It has been shown that an elaborate ongoing modulation, including Th1/Th2 cytokines, indoleamine 2,3-dioxygenase, human leukocyte antigen (HLA) molecules, regulatory T cells, costimulatory molecules, activation of immunocompetent cells, and so on, occurs in both pregnancy and transplantation, which indicates that there are parallels between models of transplant rejection and pregnancy loss (Hall et al. 1990, Wegmann et al. 1993, Arck et al. 1997, Li et al. 1998, Chaouat et al. 1999, Gorczynski et al. 2002, Piccinni 2002, Salama et al. 2003, Saito et al. 2005, Zenclussen 2005, Wilczynski 2006, Zenclussen et al. 2006). Thereby, paradigms from CsA application on transplantation shed some light on investigating the materno-fetal relationship. We speculated that CsA has the potential to suppress the unsuitable maternal immune rejection to the allogeneic fetus just as this drug has done in transplantation.

A successful pregnancy requires not only maternal tolerance to an allogeneic fetus but also the fascinating properties of trophoblast cells. The trophoblast cells are critical for appropriate materno-fetal interactions. Dysfunction of the trophoblast has been confirmed to be associated not only with spontaneous abortion but also with pre-eclampsia and fetal growth restriction (Hustin et al. 1990, de Groot et al. 1996, Ball et al. 2006,
Kadyrov et al. 2006). We have demonstrated that CsA can improve the first trimester human trophoblast cell growth and invasiveness in vitro (Yan et al. 2002a, Zhou et al. 2007). Therefore, we wondered whether CsA could also improve the biological functions in vivo of murine trophoblast cells that play key roles in the implantation, placentation, and development of embryo.

In the present study, by recruiting $\mathrm{CBA} / \mathrm{J} \times \mathrm{DBA} / 2$ matings as an abortion-prone model and $\mathrm{CBA} / \mathrm{J} \times \mathrm{BALB} / \mathrm{C}$ as a normal pregnancy model, we observed the effects of CsA, administered at the early stage of gestation, on pregnancy outcome, expression of costimulatory molecules CD80/86 and CD28/CTLA-4, and proliferation and apoptosis of murine trophoblast cells at the materno-fetal interface.

\section{Results}

\section{CsA increased fetal survival in abortion-prone matings}

In our colony, the spontaneous abortion rate in $\mathrm{CBA} / \mathrm{J} \times \mathrm{DBA} / 2$ matings was $28 \%$ (25/88), consistent with previous studies (Chaouat et al. 1983, 1985, 1995, Kiger et al. 1985). In order to test whether fetal loss could be reduced by CsA treatment in vivo, different doses of CsA or vehicle were administrated orally to the abortion-prone $\mathrm{CBA} / \mathrm{J}$ females mated with $\mathrm{DBA} / 2$ males on day 4.5 of gestation, at the window of murine implantation. The embryo resorption rate was calculated on day 14.5 of gestation. The results shown in Table 1 clearly demonstrate that different dosage of CsA treatment in abortion-prone matings significantly reduced the resorption rate of (CBA $J \times D B A / 2) \quad F_{1}$ fetuses compared with the non-treated abortion-prone matings. Dosage of $1.0 \mathrm{mg} / \mathrm{kg}$ CsA was especially significant $(P<0.01)$, and the pregnancy outcome similar to that of the successful pregnancy model $(\mathrm{CBA} / \mathrm{J} \times \mathrm{BALB} / \mathrm{c}$ matings). These findings indicate that $\mathrm{CsA}$ has the potential to improve pregnancy outcome in the abortion-prone matings (Table 1 ).

In addition, as shown in the above embryo resorption results, when treated with $\mathrm{CsA}$ of $1.0 \mathrm{mg} / \mathrm{kg}$, the resorption rate of the abortion-prone matings was the lowest and almost equivalent to that of the normal pregnancy models, thus the following studies were all performed with this optimal dosage.

Table 1 Effect of cyclosporin A ( $\mathrm{CsA}$ ) administration on the embryo resorption rate in $\mathrm{CBA} / \mathrm{J} \times \mathrm{DBA} / 2$ matings.

\begin{tabular}{|c|c|c|c|c|c|}
\hline Mating combination & Dosage of CsA (mg/kg) & Number of mice & $\begin{array}{c}\text { Implantation sites/ } \\
\text { mouse }\end{array}$ & $\begin{array}{c}\text { Number of resorbed } \\
\text { fetuses }\end{array}$ & Percent resorption \\
\hline $\mathrm{CBA} / \mathrm{J} \times \mathrm{BALB} / \mathrm{C}$ & - & 10 & $9.6 \pm 1.34$ & 8 & $8.33(8 / 96)$ \\
\hline $\mathrm{CBA} / \mathrm{J} \times \mathrm{DBA} / 2$ & Vehicle & 10 & $8.8 \pm 2.62$ & 25 & $28.00(25 / 88)^{*}$ \\
\hline $\mathrm{CBA} / \mathrm{J} \times \mathrm{DBA} / 2$ & 0.1 & 10 & $8.7 \pm 1.89$ & 13 & $14.00(13 / 87)^{\dagger}$ \\
\hline $\mathrm{CBA} / \mathrm{J} \times \mathrm{DBA} / 2$ & 1.0 & 10 & $8.6 \pm 0.97$ & 9 & $10.47(9 / 86)^{\ddagger}$ \\
\hline $\mathrm{CBA} / \mathrm{J} \times \mathrm{DBA} / 2$ & 10 & 12 & $8.2 \pm 1.47$ & 15 & $15.30(15 / 98)^{\dagger}$ \\
\hline
\end{tabular}

The embryo resorption rate was calculated using the formula presented in Materials and Methods. $\chi^{2}$ test: ${ }^{*} P<0.01$, compared with $\mathrm{CBA} / \mathrm{J} \times$ BALB/c matings; $\chi^{2}$ test: ${ }^{\dagger} P<0.05 ;{ }^{\ddagger} P<0.01$, compared with CBA/J $\times$ DBA/2 matings treated with vehicle. 

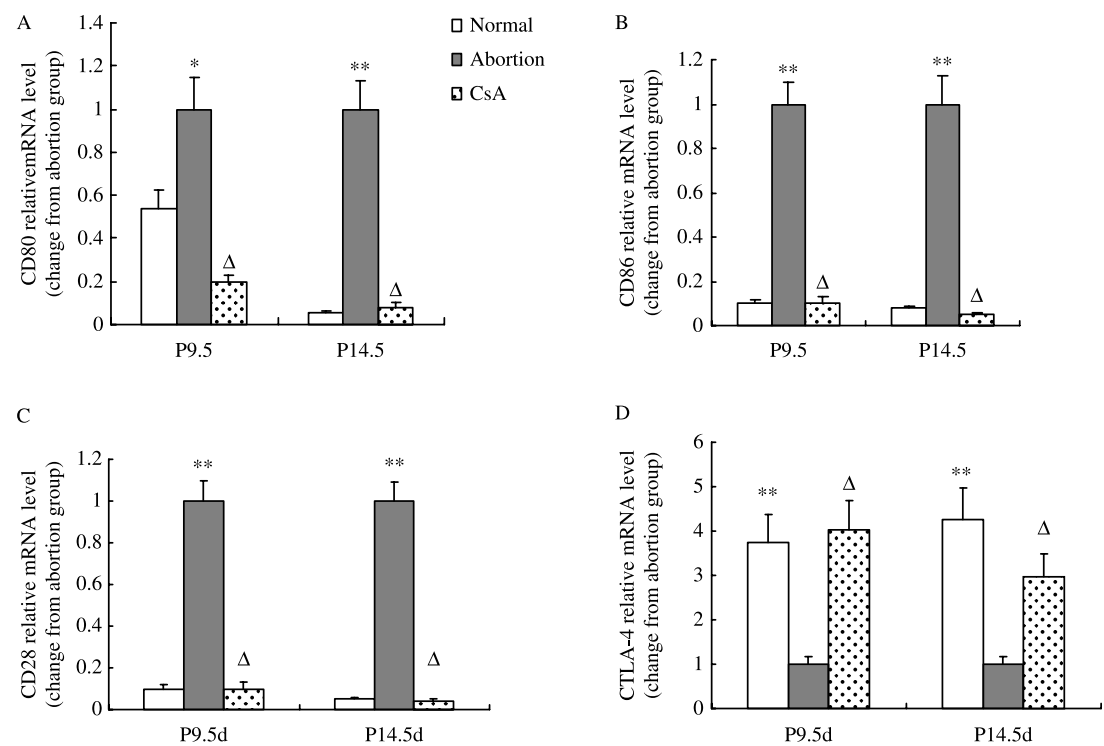

Figure 1 Modulation of CsA on mRNA level of CD80/CD86 and CD28/CTLA-4 at the materno-fetal interface. Pregnant CBA/J females mated with $\mathrm{DBA} / 2$ males were administrated orally with $0 \mathrm{mg} / \mathrm{kg}$ (abortion control) or $1.0 \mathrm{mg} / \mathrm{kg} \mathrm{CsA}$ (CsA group) on day 4.5 of gestation, and the pregnant $\mathrm{CBA} / \mathrm{J} \times \mathrm{BALB} / \mathrm{c}$ matings were also established as successful model. On day 9.5 or 14.5 of gestation, the implantation sites from the three groups were collected respectively, and the mRNA level of CD80/CD86 and CD28/CTLA-4 at the materno-fetal interface was determined by real-time RT-PCR. $\mathrm{CsA}(\mathrm{A})$ inhibited the mRNA expression of CD80, (B) down-regulated the mRNA expression of CD86, (C) decreased the mRNA expression of CD28, and (D) promoted the mRNA expression of CTLA-4 at the materno-fetal interface in abortion-prone matings. Results were reproducible in five animals. Normal, pregnant $\mathrm{CBA} / \mathrm{J} \times \mathrm{BALB} / \mathrm{c}$ matings; abortion, pregnant $\mathrm{CBA} / \mathrm{J} \times \mathrm{DBA} / 2$ matings; $\mathrm{Cs}$, pregnant $\mathrm{CBA} / \mathrm{J} \times \mathrm{DBA} / 2$ matings treated with CsA $(1.0 \mathrm{mg} / \mathrm{kg})$ on day 4.5 of gestation. P9.5d, on day 9.5 of gestation and $\mathrm{P} 14.5 \mathrm{~d}$, on day 14.5 of gestation. ${ }^{*} P<0.05$ and ${ }^{* *} P<0.01$ compared with the successful control; ${ }^{\Delta} P<0.01$ compared with the abortion control. Error bars depict the s.E.M.

\section{Effect of CsA on transcription of CD80/CD86 and CD28/CTLA-4 at the materno-fetal interface}

CD80 (B7-1)/CD86 (B7-2) and CD28/CTLA-4, as two main costimulatory molecule pairs, play crucial roles in the activation, proliferation, and differentiation of $\mathrm{T}$ lymphocytes, which participate in antigen-specific rejection (Bhatia et al. 2005). In this study, the mRNA level of CD80/CD86 and CD28/CTLA-4 at the maternofetal interface was determined by real-time RT-PCR. The results in Fig. 1 clearly show that the mRNA level of CD80/86 and CD28 at the materno-fetal interface in abortion-prone matings was obviously higher than that of the successful matings, while administration of CsA $(1.0 \mathrm{mg} / \mathrm{kg})$ at the window of implantation remarkably reduced the aberrant expression of these costimulatory molecules. On the contrary, compared with the successful matings, the mRNA level of CTLA-4 at the materno-fetal interface in abortion-prone matings was significantly lower, while the mRNA expression of CTLA-4 was up-regulated and almost equivalent to that of the normal pregnancy matings after CsA treatment.

\section{Immunocytochemical identification for the purity of murine ectoplacental-derived trophoblasts}

The identification of the ectoplacental-derived trophoblastic cells was confirmed by immunocytochemistry with anti-cytokeratin-7 and anti-vimentin antibody. It is clearly shown in Fig. 2 that the isolated majority of cells were stained positive for cytokeratin-7 (Fig. 2A) and negative for vimentin (Fig. 2B). The purity of the isolated trophoblast cells was above $95 \%$.

\section{CsA-promoted expression of proliferating cell nuclear antigen (PCNA) of murine ectoplacental-derived trophoblasts in abortion-prone matings}

The capacity of CsA to promote the murine trophoblast proliferation was investigated through PCNA analysis by flow cytometry. The results showed that the PCNA expression of ectoplacental-derived trophoblastic cells in abortion-prone matings was significantly lower than that of the successful matings, while the number of trophoblasts
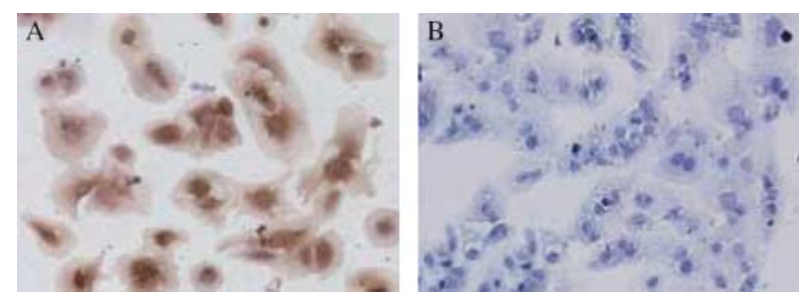

Figure 2 Immunostaining of cytokeratin-7 and vimentin in murine trophoblast cells. In $24 \mathrm{~h}$ culture, the cells were characterized by staining of cytokeratin-7 and vimentin. (A) Stained by anti-cytokeratin-7 $\mathrm{mAb}$. (B) Stained by anti-vimentin mAb. Magnification $\times 200$. The purity of the isolated murine trophoblast cells was more than $95 \%$. 

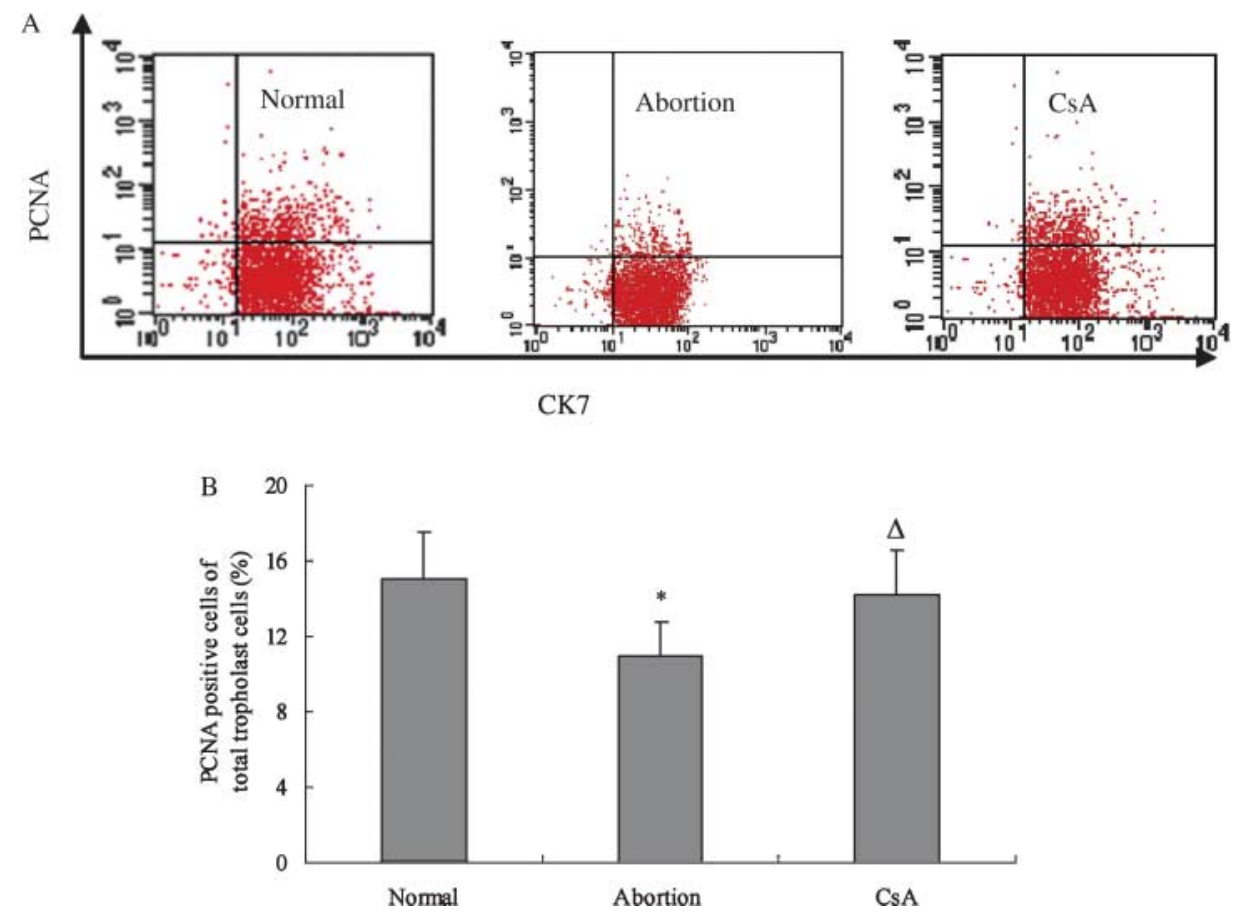

Figure 3 CsA-promoted expression of PCNA of murine trophoblast cells in abortion-prone matings. The freshly isolated murine trophoblasts from the successful, abortion-prone or CsA $(1.0 \mathrm{mg} / \mathrm{kg})$ treated abortion-prone matings were stained by PCNA and cytokeratin-7 respectively and then analyzed by flow cytometry for the level of PCNA. (A) The typical flow cytometry profiles. (B) Percentage of PCNA positive cells. The expression of PCNA in trophoblast cells in abortion-prone matings was significantly lower than that of the successful matings, while the percentage of PCNA positive cells remarkably increased after treatment with $1.0 \mathrm{mg} / \mathrm{kg}$ of $\mathrm{CsA}$, and was even similar to that of the successful matings. Results were reproducible in five animals. ${ }^{*} P<0.05$ compared with the successful control; ${ }^{\Delta} P<0.05$ compared with the abortion-prone control. Normal, $\mathrm{CBA} / \mathrm{J} \times \mathrm{BALB} / \mathrm{C}$ matings; abortion, $\mathrm{CBA} / \mathrm{J} \times \mathrm{DBA} / 2$ matings; $\mathrm{CsA}, \mathrm{CBA} / \mathrm{J} \times \mathrm{DBA} / 2$ matings treated with $\mathrm{CsA}(1.0 \mathrm{mg} / \mathrm{kg})$ on day 4 of gestation. Error bars depict the S.E.M.

expressing PCNA in abortion-prone matings remarkably increased after treatment with $1.0 \mathrm{mg} / \mathrm{kg} \mathrm{CsA}$, and the proportion of PCNA-positive cells even approached that of the successful pregnant matings, suggesting that CsA treatment has the potential to promote proliferation in vivo of murine trophoblasts (Fig. 3).

\section{CsA down-regulated apoptosis of ectoplacental-derived trophoblastic cells in abortion-prone matings}

Since CsA is able to affect a wide spectrum of cell apoptosis (Borutaite et al. 2003), we observed the effect of CsA on apoptosis of murine trophoblasts. By Annexin $\mathrm{V}$ and propidium iodide (PI) staining and subsequent flow cytometric analysis, the number of cells undergoing apoptosis was determined. The apoptosis of ectoplacental-derived trophoblastic cells in abortion-prone matings significantly increased, compared with the successful matings, while CsA $(1.0 \mathrm{mg} / \mathrm{kg})$ treatment remarkably reduced the percentage of trophoblast cells undergoing apoptosis, and the proportion of trophoblast cells undergoing apoptosis in CsA-treated abortion models was reduced to that of the successful matings, which suggests that CsA has potential to inhibit apoptosis and improve the function of murine trophoblasts in abortion-prone matings (Fig. 4).

\section{Discussion}

At the materno-fetal interface, the expression of CD80/86 and class II antigens is absent on extravillous trophoblast cells, and mainly localized to antigenpresenting cells (APCs) (Athanassakis-Vassiliadis et al. 1990, Vassiliadis et al. 1994, Athanassakis et al. 1995, Petroff et al. 2003). The dendritic cell (DC), the most potent presenter at the materno-fetal interface, has characteristics of itself, including the predominance of myeloid DCs over lymphoid DCs; high proportion of immature DCs to mature DCs, a moderate expression of CD80/86; co-expression of CD86/HLA-DR; more production of interleukin (IL)-10 than that of IL-12, which is beneficial to the development of 'tolerogenic' DCs and induction of immune tolerance to the embryo (Kammerer et al. 2000, Gardner \& Moffett 2003, Kammerer et al. 2003, Blois et al. 2004, Rieger et al. 2004). The induced class II antigens expression at the spongiotrophoblastic zone of the murine placenta significantly correlates with fetal abortion and developmental abnormalities (Athanassakis-Vassiliadis et al. 

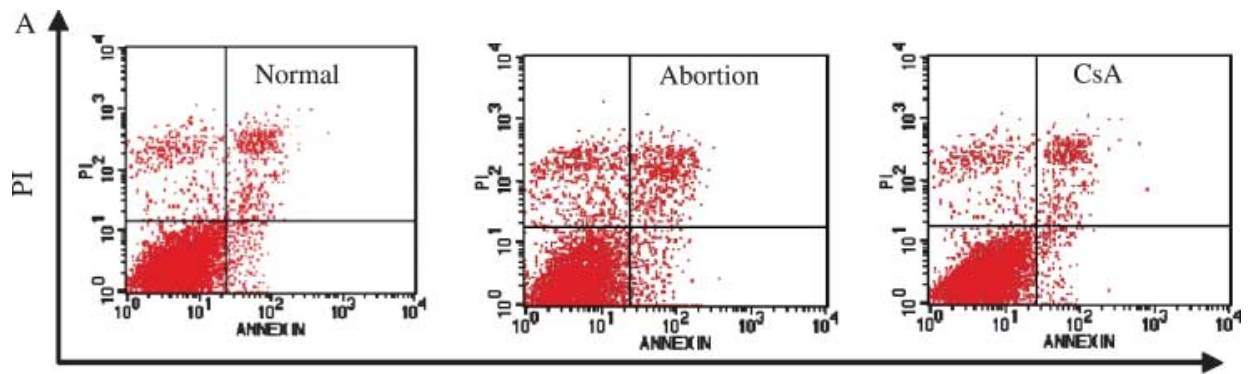

Annexin V

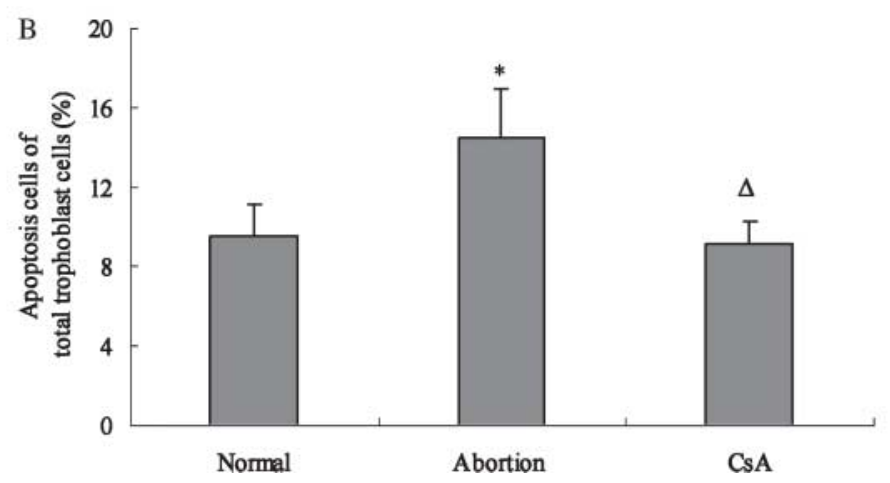

Figure 4 CsA down-regulated apoptosis of murine trophoblast cells in abortion-prone matings. The freshly isolated murine trophoblasts from the successful, abortion-prone or CsA $(1.0 \mathrm{mg} / \mathrm{kg}$ ) treated abortion-prone matings were stained by Annexin $\mathrm{V}$ and PI respectively and then analyzed by flow cytometry for the cells undergoing apoptosis. (A) The typical flow cytometry profiles. (B) Percentage of cells undergoing apoptosis. The apoptosis of trophoblast cells in abortion-prone matings was significantly higher than that of the successful matings, while the percentage of cells undergoing apoptosis was remarkably reduced after treatment with $1.0 \mathrm{mg} / \mathrm{kg}$ of CsA, and was even similar to that of the successful matings. Results were reproducible in five animals. ${ }^{*} P<0.05$ compared with the successful control; ${ }^{\Delta} P<0.05$ compared with the abortion-prone control. Normal, $\mathrm{CBA} / \mathrm{J} \times \mathrm{BALB} / \mathrm{c}$ matings; abortion, $\mathrm{CBA} / \mathrm{J} \times \mathrm{DBA} / 2$ matings; $\mathrm{CsA}, \mathrm{CBA} / \mathrm{J} \times \mathrm{DBA} / 2$ matings treated with $\mathrm{CsA}(1.0 \mathrm{mg} / \mathrm{kg})$ on day 4 of gestation. Error bars depict the S.E.M.

1990, Vassiliadis et al. 1994). Our present study also found that there was an increased expression of CD80/ 86 and CD28, while a decreased expression of CTLA-4 at the materno-fetal interface in $\mathrm{CBA} / \mathrm{J} \times \mathrm{DBA} / 2$ abortionprone models. The interaction of CD80/CD86 with $\mathrm{CD} 28$ is one of the vital costimulatory regulations that deliver costimulatory signals, activate T cells, and lead to immunorejection (Guinan et al. 1994, June et al. 1994). It was found, in our previous studies, that at the maternofetal interface in $\mathrm{CBA} / \mathrm{J} \times \mathrm{DBA} / 2$ abortion-prone models, the production of Th1 cytokines up-regulated while that of Th2 cytokines down-regulated (Jin et al. 2004, Zhu et al. 2005, Du et al. 2007). We also found that the embryo resorption rate of $\mathrm{CBA} / \mathrm{J} \times \mathrm{DBA} / 2$ abortion-prone models decreased after in vivo CD80/86 mAbs treatment and blocking costimulatory signals CD80/86 could suppress maternal immune attack to the fetus by shifting cytokines from Th1 predominance to Th2 bias at the materno-fetal interface and expanding peripheral $\mathrm{CD} 4{ }^{+} \mathrm{CD} 25^{+}$regulatory $\mathrm{T}$ cells (Jin et al. 2004, Zhu et al. 2005). Thus, it is reasonable to propose that a limited and proper expression of costimulatory molecules on some specific cells, for example, DCs at the materno-fetal interface, might contribute to the appropriate and regional activation of $\mathrm{T}$ cells via conducting suitable signals, leading to T-cell tolerance to the semi-allogeneic embryo, and an over-expression of costimulatory molecules might play important roles in the pathology of pregnancy loss via excessive activation of maternal immune cells, leading to attack of the fetus.

In the present study, it has been demonstrated that the abnormal expression of both CD80/86 and CD28 at the materno-fetal interface in abortion-prone models $(\mathrm{CBA} / \mathrm{J} \times \mathrm{DBA} / 2$ matings) was down-regulated after CsA treatment at the early stage of pregnancy, and the level of CD80/CD86 and CD28 at the materno-fetal interface in CsA-treated abortion-prone models was almost reduced to that of normal models (CBA $\times$ BALB/C matings). Our previous study has demonstrated that CsA administrated at the window of implantation could induce a Th2 bias and expansion of $\mathrm{CD} 4{ }^{+} \mathrm{CD} 25^{+}$regulatory $\mathrm{T}$ cells in the abortion-prone $\mathrm{CBA} / \mathrm{J} \times \mathrm{DBA} / 2$ matings (Du et al. 2007). It has also been shown, in our previous research, that blocking costimulation signals CD80/ 86 could suppress maternal immune attack to the fetus by shifting cytokines from Th1 predominance to Th2 bias at the materno-fetal interface and expanding 
peripheral $\mathrm{CD} 4{ }^{+} \mathrm{CD} 25^{+}$regulatory $\mathrm{T}$ cells; furthermore, the expression of CD28 and its ligands CD80/ CD86 on peripheral lymphocytes was downregulated (Jin et al. 2004, Zhu et al. 2005). Thus, it could be speculated that the down-regulation of CsA on CD80/CD86 and CD28 might contribute to the induction of a Th2 bias and development of maternofetal tolerance, which is beneficial to suppressing maternal rejection to fetus and improving the pregnancy outcome of the abortion-prone matings.

It has become evident that $\mathrm{T}$ cells are sensitive to quantitative changes in the molecular interactions that contribute to T-cell antigen recognition, and all these quantitative changes, including binding affinity, kinetics, or surface density, can lead to different T-cell responses (Jameson \& Bevan 1995, Sykulev et al. 1995, Alam et al. 1996, Valitutti et al. 1996, Viola \& Lanzavecchia 1996, van der Merwe \& Davis 2003). As another receptor for CD80/CD86, CTLA-4 (cytotoxic T lymphocytes-associated antigen-4, CD152) shares a similar molecular architecture with CD28, existing as disulfide-linked homodimers of Ig variable domains (Peach et al. 1994, Greene et al. 1996). The interaction of CD28 with B7 ligands delivers a positive signal to $\mathrm{T}$ cells that promotes proliferation and IL-2 secretion (Thompson et al. 1989, Linsley et al. 1991). In contrast, the interaction of CTLA-4 with B7 ligands attenuates T-cell activation and induces T-cell anergy (Walunas et al.1994, Tivol et al. 1995, Waterhouse et al. 1995). Our work showed that CsA down-regulated the expression of CD28, while up-regulating the expression of CTLA-4 at the materno-fetal interface in the abortion-prone matings, and the level of CTLA-4 and CD28 in CsA-treated abortion-prone matings almost approached that of normal models, which suggests that CsA can correct the aberrant expression pattern of CD28 and CTLA-4 in abortionprone matings. CD80 bound to CTLA- 4 and CD28 with $\mathrm{Kd}$ values of 0.2 and $4.0 \mu \mathrm{M}$ respectively; and CD86 bound to CTLA-4 and CD28 with Kd values 20.0 and $2.6 \mu \mathrm{M}$ respectively, suggesting that CTLA- 4 has a higher affinity to CD80/86 than CD28 (van der Merwe et al. 1997, Collins et al. 2002). Thus, the up-regulation of CTLA- 4 and down-regulation of CD28 by CsA treatment might further reinforce the competitive ability of CTLA-4 for CD80/86. In this condition, CsA could provide us with twofold guarantees: this drug first suppresses the activation of $\mathrm{T}$ cells through down-regulating the abnormal expression of CD80/86 and CD28 in abortion-prone matings, and then delivers activation-induced inhibitory signals through up-regulating the level of CTLA-4, which redounds to the prevention of the fetus from maternal rejection and the induction of maternofetal tolerance.

The $\mathrm{CD} 4{ }^{+} \mathrm{CD} 25^{+}$regulatory $\mathrm{T}$ cells (Treg) have recently been described as a unique subpopulation of T cells (Wood \& Sakaguchi 2003, Sakaguchi 2004, Waldmann et al. 2004). They have been confirmed to play a major role in preventing autoimmunity and tolerating allogeneic organ grafts (Sakaguchi et al. 1995, Zelenika et al. 2001, Kingsley et al. 2002). The proportion of $\mathrm{CD} 4{ }^{+} \mathrm{CD} 25^{+}$regulatory $\mathrm{T}$ cells at the materno-fetal interface is low, but these cells have been regarded as one of the important mediators inducing embryonic antigen-specific tolerance (Heikkinen et al. 2004, Saito et al. 2005, Zenclussen 2005, Zenclussen et al. 2006). CTLA-4 is a functional molecule for $\mathrm{CD} 4{ }^{+} \mathrm{CD} 25^{+}$regulatory $\mathrm{T}$ cells, and can deliver inhibitory signals via direct cell-cell interaction (Thornton \& Shevach 1998, Takahashi et al. 2000, Bensinger et al. 2001). We determined only the whole level of CTLA-4 at the materno-fetal interface; however, this molecule is constituently expressed at the surface of $\mathrm{CD} 4{ }^{+} \mathrm{CD} 25^{+}$regulatory $\mathrm{T}$ cells, and the $\mathrm{CD} 4{ }^{+} \mathrm{CD} 25^{+}$ regulatory $T$ cells do exist at the materno-fetal interface (Takahashi et al. 2000, Bensinger et al. 2001). It was found in our present study that the expression of CD80/86 at the materno-fetal interface in abortionprone models decreased after CsA treatment. Furthermore, our previous research has shown that CsA could expand $\mathrm{CD} 4{ }^{+} \mathrm{CD} 25^{+} \mathrm{Foxp}^{+}$regulatory $\mathrm{T}$ cells in abortion-prone matings, and CD80/86 blockade could also induce expansion and CTLA-4 expression of $\mathrm{CD} 4{ }^{+} \mathrm{CD} 25^{+}$Foxp3 $^{+}$regulatory $\mathrm{T}$ cells in these abortion models (Jin et al. 2004, Zhu et al. 2005, Du et al. 2007). Thus, it is speculated that CsA might enhance both the number and the function of $\mathrm{CD} 4{ }^{+} \mathrm{CD} 25^{+}$ regulatory $\mathrm{T}$ cells by down-regulating CD80/86, which might facilitate fetal survival and development in the abortion-prone matings. Of course, this hypothesis deserves further investigation.

Besides maternal tolerance to the embryo, the fascinating property of trophoblast cells is another key player for a successful pregnancy. In mice and other rodents, trophoblast cells are the placental cells in direct contact with endometrial tissues throughout gestation (Billington 1971, Muntener \& Hsu 1977). These cells play crucial roles in implantation and placentation (Muntener \& Hsu 1977, Bevilacqua \& Abrahamsohn 1988, Mehrotra 1988, Kanai-Azuma et al. 1993). After the onset of implantation, the trophoblast cells even have the ability to phagocytose the maternal components (cells interposed in the invasion pathway, as well as substantial numbers of blood cells). It has been reported that this phagocytic activity participates in fetal nutrition prior to complete formation of the placenta, and also plays a role in acquiring space for embryo attachment and development in the endometrium (Welsh \& Enders 1987, Bevilacqua \& Abrahamsohn 1988). Thus, the accurate function of trophoblasts is crucial to normal pregnancy. It has been demonstrated that an insufficient proliferation or increased apoptosis of trophoblasts is highly linked with both murine and human pregnancy failure (Qumsiyeh et al. 2000, Olivares et al. 2002, Greer 2003, Burdon et al. 2007). The interesting point is that our work showed that the expression of PCNA 
of ectoplacental-derived trophoblastic cells increased and the level of Annexin $\mathrm{V}$ in these cells decreased after CsA treatment at the window of murine implantation, compared with the non-treated abortion-prone matings, suggesting that this drug presents a favorable effect on murine trophoblasts via promoting proliferation and suppressing apoptosis of these cells. It was demonstrated, in our previous research, that CsA was able to directly promote in vitro growth of the first trimester human cytotrophoblasts (Yan et al. 2002a). Moreover, our recent study also found that different from its actions on immune cells via the calcineurin/calmodulin/NF-AT signals, CsA enhanced the invasiveness and activity of matrix metalloproteinase (MMP)9 and MMP2 in vitro of first-trimester human trophoblast cells through activation of MAPK/ ERK1/2 signaling pathway (Zhou et al. 2007). Therefore, CsA may present different effects on different cells via different signaling pathways, and the pharmacological action of this drug is far from being completely understood and deserves further investigation. It is evident that the decidual local and peripheral lymphocytes are overactivated and produce aberrant Th1-related cytokines in spontaneous abortion, leading to extensive destruction of the trophoblast by inducing apoptosis (Hill et al. 1995, Abadia-Molina etal. 1996, Bates et al. 2002, Olivares etal. 2002). Thus, it is proposed that CsA might modulate the biological function of trophoblast cells in vivo in both a direct (MAPK signaling pathway) and an indirect manner suppressing lymphocyte activation by down-regulating co-stimulatory molecules, which are all beneficial to the improvement of trophoblast functions in the abortionprone matings.

Our study has demonstrated for the first time that CsA has dual functions: inducing the materno-fetal immunotolerance, and improving the biological functions of trophoblast cells, which is propitious to improve the pregnancy outcome in abortion-prone matings. In addition, our previous study showed that there was no remarkable difference in the weight of viable placentas and fetuses between the $\mathrm{CBA} / \mathrm{J} \times \mathrm{DBA} / 2$ abortioncontrol group and the $\mathrm{CBA} / \mathrm{J} \times \mathrm{DBA} / 2 \mathrm{CsA}$-treated group, suggesting that $\mathrm{Cs} A$ treatment on the window of implantation could improve the outcome of the abortion-prone models, while having no obvious inhibition in the weight of placentas and fetuses of the $\mathrm{CBA} / \mathrm{J} \times \mathrm{DBA} / 2$ abortion-prone matings. Furthermore, no significant difference in the embryo resorption rate and the weight of placentas and fetuses was observed between the $C B A \times B A L B / C$ normal group and the $\mathrm{CBA} \times \mathrm{BALB} / \mathrm{C}$ normal CsA-treated group, which suggests that a low dosage of CsA treatment at day 4.5 of gestation has no obvious side effect on normal pregnancies (Yan et al. 2002b). Therefore, CsA appears to be useful as an immunological therapy for spontaneous abortion. Of course, the safety for clinical administration deserves further investigation.

\section{Materials and Methods}

\section{Mice}

Inbred strains female mice of 8 -week-old CBA/J $\left(\mathrm{H}-2^{k}\right)$, male DBA/2 $\left(\mathrm{H}-2^{\mathrm{d}}\right)$ and BALB/C $\left(\mathrm{H}-2^{\mathrm{d}}\right)$ were obtained from the Jackson Laboratories (Bar Habor, ME, USA), and subsequently maintained in the Laboratory Animal Facility of the Chinese Academy of Sciences (Shanghai, China). The weight of mice ranged from 18 to $22 \mathrm{~g}$. They were usually maintained for 2 weeks in the animal facility before use. The housing and handling of the experimental animals were in accordance with the guidelines of the Chinese Council for Animal Care. The day of appearance of a copulatory plug was arbitrarily designated as day 0.5 of gestation.

\section{CsA administration}

The abortion-prone CBA/J females mated with DBA/2 males were administrated orally with 0, 0.1, 1.0, or $10 \mathrm{mg} / \mathrm{kg}$ CsA (Novartis, Basel, Switzerland) on day 4.5 of gestation, at the window of murine implantation. The pregnant $\mathrm{CBA} / \mathrm{J} \times \mathrm{BALB} / \mathrm{c}$ matings were considered as successful pregnancy model. These pregnant CBA/J mice were killed on either day 9.5 or 14.5 of gestation for further investigation.

\section{Embryo resorption}

For macroscopic observation of embryo resorption, mice were killed on day 14.5 of gestation, and the uteri were examined for the number of healthy and resorbed embryos. At this stage of gestation, the resorbed embryos were subjected to ischemia, hemorrhage, and necrosis, making them smaller and darker than the larger, pink, viable embryos. Percentage of embryos undergoing resorption was calculated by the formula described previously: $\% R=(\operatorname{Re} /(\operatorname{Re}+F)) \times 100 \%$, where $\operatorname{Re}$ represents the number of the resorbed embryos and $F$ represents the number of viable embryos (Chaouat et al. 1983, 1985, 1995, Kiger et al. 1985).

\section{Quantitative RT-PCR for $m R$ RA expression of CD80/86 and CD28/CTLA-4 at the materno-fetal interface}

Total RNA from the entire implantation site, including placental and decidual tissue, on day 9.5 or 14.5 of gestation was extracted by using Trizol reagent (Invitrogen) and reversely transcribed as previously described (Wu et al. 2004). The cDNA (5 $\mu \mathrm{l})$ was amplified by real-time PCR in a final volume of $50 \mu$ l containing $25 \mu \mathrm{l}$ real-time PCR Master Mix (TOYOBO company, Tokyo, Japan), $0.8 \mu \mathrm{mol} / \mathrm{l}$ of each primer, and $5 \mu \mathrm{mol} / / \mathrm{T}$ TagMan probe. Each sample was analyzed in duplicates, and the reaction was followed by 40 cycles of $1 \mathrm{~min}$ at $95^{\circ} \mathrm{C}, 15 \mathrm{~s}$ at $95^{\circ} \mathrm{C}$, and $1 \mathrm{~min}$ at $60^{\circ} \mathrm{C}$ using $\mathrm{ABI}$ Prism 7000 Sequence Detector. Sequences for primers and probes are shown in Table 2.

\section{Isolation of ectoplacental cone-derived trophoblasts}

The detailed description of the procedure used to isolate trophoblasts has been reported in our previous publication $(\mathrm{Wu}$ et al. 2004). Briefly, the uterine horns of pregnant CBA/J mice 
on day 9.5 of pregnancy were opened longitudinally, and the fetoplacental unit was separated from the uterine implantation sites. After washing in cold Hanks' balanced salt solution, the ectoplacental cell cone was further removed from the fetoplacental unit and cut into small pieces $\left(\sim 1 \mathrm{~mm}^{3}\right)$. The obtained tissue was digested in four cycles of $10 \mathrm{~min}$ by $0.25 \%$ trypsin (Bio Basic Inc., Ontario, Canada) and $0.02 \%$ DNase type I (Sigma) at $37^{\circ} \mathrm{C}$ with gentle agitation. The cell suspensions trypsinized each time were pooled and carefully layered over a discontinuous Percoll Gradient (65-20\%, in 5\% steps), and centrifuged at $1000 \mathrm{~g}$ (2000 r.p.m.) for $20 \mathrm{~min}$. The cells sedimenting at densities between 1.048 and $1.062 \mathrm{~g} / \mathrm{ml}$ were collected, and washed with DMEM-high glucose medium. The cells were then diluted to $1 \times 10^{6}$ cells $/ \mathrm{ml}$, maintained in DMEM-high glucose complete medium containing 10\% heat-inactivated FBS (Gibco) and incubated in 24-well plates (precoated with coverlips) at $37{ }^{\circ} \mathrm{C}$ with $5 \%$ $\mathrm{CO}_{2}$ for following immunocytochemical characterization.

\section{Immunocytochemistry}

After $24 \mathrm{~h}$ culture, the trophoblast cells were fixed in $4 \%$ polyformaldehyde for $20 \mathrm{~min}$ at room temperature, washed in PBS, and permeabilized for $4 \mathrm{~min}$ in $0.3 \%$ Triton X-100-PBS. The cells were then incubated with $7 \%$ horse serum in PBS for 30 min to block the nonspecific binding. The primary antibodies diluted in PBS containing 1\% BSA were added, and anti-mouse cytokeratin-7 lgG1 (Golden Bridge Biotechnology Co. Ltd, Beijing, China) and anti-mouse vimentin $\lg \mathrm{G} 1$ monoclonal antibody (Golden Bridge Biotechnology Co. Ltd) were used as markers for cells of trophoblast lineage. Isotype-matched irrelevant IgG (Sino-America Co. Ltd, Shanghai, China) was used as control. After incubation with the primary antibody overnight at $4{ }^{\circ} \mathrm{C}$, the cells were washed in PBS- $0.1 \%$ Tween, and then incubated with a horseradish peroxidase (HRP)-labeled secondary antibody (Sino-America Co. Ltd) for $2 \mathrm{~h}$ at room temperature. Streptavidin-HRP was applied for another $30 \mathrm{~min}$ at room temperature (avidin-biotin histostain kit, Sino-America Co. Ltd). The slides were stained with 3, 3'-diaminobenzidine, and counterstained with hematoxylin. The experiments were repeated three times.

\section{Flow cytometry of PCNA expression in murine trophoblasts}

The PCNA is a protein of $36 \mathrm{kDa}$ molecular weight and synthesized in early G1 and S phases of the cell cycle, thus can represent the proliferation ability of cells (Das-Bradoo et al. 2006). In the present study, on day 9.5 of gestation, the freshly isolated ectoplacental-derived trophoblastic cells were washed and fixed in $70 \%$ methanol at $4{ }^{\circ} \mathrm{C}$ for $30 \mathrm{~min}$. After blocking with $10 \%$ FBS, the recovered cells were added with anti-mouse PCNA-PE monoclonal antibody (eBioscience, San Diego, CA, USA) and anti-mouse cytokeratin-7-FITC monoclonal antibody (Chemicon, Temecula, CA, USA). After incubation in darkness for $30 \mathrm{~min}$ at room temperature, the cells were analyzed immediately by flow cytometry (BD Bioscience, Franklin Lakes, NJ, USA). The experiments were repeated four times.

\section{Annexin $V$ and PI staining}

To determine apoptosis of murine trophoblast cells, an Apoptosis Detection Kit was used for Annexin $\mathrm{V}$ binding and PI staining (Bender, Burlingame, CA, USA). The freshly isolated ectoplacental-derived trophoblastic cells were washed and resuspended in $80 \mu \mathrm{l}$ binding buffer (10 mM HEPES, $140 \mathrm{mM}$ sodium chloride, $2.5 \mathrm{mM}$ calcium chloride, $\mathrm{pH}$ 7.4). To each cell suspension was added $10 \mu \mathrm{l}$ fluorescence-conjugated Annexin $\mathrm{V}(10 \mu \mathrm{g} / \mathrm{ml})$ and $10 \mu \mathrm{l} \mathrm{Pl}$ reagent $(50 \mu \mathrm{g} / \mathrm{ml})$. The cells were mixed and then incubated in the dark for $15 \mathrm{~min}$ at room temperature. At the end of incubation, a further $400 \mu \mathrm{l}$ binding buffer was added, and the cells were analyzed immediately by flow cytometry (BD Bioscience). The control tubes of unstained cells, cells stained with PI alone, and cells stained with Annexin $V$ only were included for setting up the flow cytometric compensation.

\section{Statistical analysis}

All values shown are mean \pm s.E.M. The significance of difference in the resorption rates was tested by a $\chi^{2}$ test. Student's $t$-test was performed to detect the significance of difference in the expression of costimulatory molecules at

Table 2 The primer sequences and probes for CD80/CD86 and CD28/CTLA-4 by real-time RT-PCR.

\begin{tabular}{|c|c|}
\hline Mouse & Primers and probes \\
\hline \multirow[t]{3}{*}{ GAPDH } & GAPDH-R: 5'-CACCCCATTTGATGTTAGTG-3' \\
\hline & GAPDH-F: 5'-CCATTTGCAGTGGCAAAG-3' \\
\hline & GAPDH-probe: 5'-FAM-CAAGGCCGAGAATGGGAAGCTTGTC-TAMRA-3' \\
\hline \multirow[t]{3}{*}{ CD28 } & CD28-R (bp622C): 5'-TGGTAAGGCTTTCGAGTGAG-3' \\
\hline & CD28-F (bp499): 5'-ATGGCTTGCTAGTGACAGTG-3' \\
\hline & CD28-probe: 5'FAM-TGACTACATGAACATGACTCCCCG-TAMRA $3^{\prime}$ \\
\hline \multirow[t]{3}{*}{ CD80 } & CD80-R (bp915C): 5'-GAAGACGGTCTGTTCAGCTA-3' \\
\hline & CD80-F (bp737): 5'-ACACACTTGTGCTCTTTGGG-3' \\
\hline & CD80-probe: 5'FAM-TTCGGCGCAGTAATAACAGTCGTC-TAMRA3' \\
\hline \multirow[t]{3}{*}{ CD86 } & CD86-R (bp958C): 5'-CTCTGTCAGCGTTACTATCC-3' \\
\hline & CD86-F (bp829): 5'-ACAGCTTCAGTTACTGTGGC-3' \\
\hline & CD86-probe: 5'FAM-ATGTCACAAGAAGCCGAATCAGCC-TAMRA3' \\
\hline \multirow[t]{3}{*}{ CTLA-4 } & CTLA-4-R (bp662C): 5'-CAAGCTAACTGCGACAAGGA-3' \\
\hline & CTLA-4-F (bp525): 5'-TACCTCTGCAAGGTGGAACT-3' \\
\hline & CTLA-4-probe: 5'FAM-ATGCCCGGATTCTGACTTCCTCCT-TAMRA $3^{\prime}$ \\
\hline
\end{tabular}


the materno-fetal interface, and in the level of PCNA and annexin $\mathrm{V}$ in murine trophoblasts. Differences were accepted as significant at $P<0.05$.

\section{Acknowledgements}

This work was supported by National Basic Research Program of China 2006CB944009 (to D-J Li), 985 Foundations of Fudan University No. 985B36 (to D-J Li), Shanghai Foundations for Basic Research No.03JC14016 (to D-J Li), and No.06ZR14120 (to M-R Du), and Program for Outstanding Medical Academic Leader (to D-J Li). The authors declare that there is no conflict of interest that would prejudice the impartiality of this scientific work.

\section{References}

Abadia-Molina AC, Ruiz C, Montes MJ, King A, Loke YW \& Olivares EG 1996 Immune phenotype and cytotoxic activity of lymphocytes from human term decidua against trophoblast. Journal of Reproductive Immunology 31 109-123.

Alam SM, Travers PJ, Wung JL, Nasholds W, Redpath S, Jameson SC \& Gascoigne NRJ 1996 T-cell-receptor affinity and thymocyte positive selection. Nature 381 616-620.

Arck PC, Troutt AB \& Clark DA 1997 Soluble receptors neutralizing TNFa and IL-1 block stress-triggered murine abortion. American Journal of Reproductive Immunology 37 262-268.

Athanassakis I, Aifantis Y, Makrygiannakis A, Koumantakis E \& Vassiliadis S 1995 Placental tissue from human miscarriages express class II MHC antigens. American Journal of Reproductive Immunology 34 281-287.

Athanassakis-Vassiliadis I, Galanopoulos VK, Grigoriou M \& Papamatheakis J 1990 Induction of class II MHC antigen expression on the murine placenta by 5 -azacytidine correlates with fetal abortion. Cellular Immunology 128 438-449.

Ball E, Bulmer JN, Ayis S, Lyall F \& Robson SC 2006 Late sporadic miscarriage is associated with abnormalities in spiral artery transformation and trophoblast invasion. Journal of Pathology 208 535-542.

Bates MD, Quenby S, Takakuwa K, Johnson PM \& Vince GS 2002 Aberrant cytokine production by peripheral blood mononuclear cells in recurrent pregnancy loss? Human Reproduction 17 2439-2444.

Bensinger SJ, Bandeira A, Jordan MS, Caton AJ \& Laufer TM 2001 Major histocompatibility complex class II-positive cortical epithelium mediates the selection of $\mathrm{CD} 4(+) \mathrm{CD} 25(+)$ immunoregulatory T cells. Journal of Experimental Medicine 194 427-438.

Bevilacqua E \& Abrahamsohn PA 1988 Ultrastructure of trophoblast giant cell transformation during the invasive stage of implantation of the mouse embryo. Journal of Morphology 198 341-351.

Bhatia S, Edidin M, Almo SC \& Nathenson SG 2005 Different cell surface oligomeric states of B7-1 and B7-2: implications for signaling. PNAS 102 15569-15574.

Billington WD 1971 Biology of the trophoblast. In Advances in Reproductive Physiology, pp 27-66. Ed. MNH Bishop. London: Logos Press.

Blois SM, Alba Soto CD, Tometten M, Klapp BF, Margni RA \& Arck P 2004 Lineage, maturity, and phenotype of uterine murine dendritic cells throughout gestation indicate a protective role in maintaining pregnancy. Biology of Reproduction 70 1018-1023.

Borutaite V, Jekabsone A, Morkuniene R \& Brown GC 2003 Inhibition of mitochondrial permeability transition prevents mitochondrial dysfunction, cytochrome c release and apoptosis induced by heart ischemia. Journal of Molecular and Cellular Cardiology 35 357-366.

Burdon C, Mann C, Cindrova-Davies T, Ferguson-Smith AC \& Burton GJ 2007 Oxidative stress and the induction of cyclooxygenase enzymes and apoptosis in the murine placenta. Placenta 28 724-733.

Chao KH, Wu MY, Chen CD, Yang JH, Yang YS \& Ho HN 1999 The expression of killer cell inhibitory receptors on natural killer cells and activation status of CD4 + and CD8 + T cells in the decidua of normal and abnormal early pregnancies. Human Immunology 60 791-797.
Chaouat G, Kiger N \& Wegmann TG 1983 Vaccination against spontaneous abortion in mice. Journal of Reproductive Immunology 5 389-392.

Chaouat G, Kolb JP, Kiger N, Stanislawski M \& Wegmann TG 1985 Immunologic consequences of vaccination against abortion in mice. Journal of Immunology 134 1594-1598.

Chaouat G, Assal Meliani A, Martal J, Raghupathy R, Elliott JF, Mosmann T \& Wegmann TG 1995 IL-10 prevents naturally occurring fetal loss in the CBA DBA/2 mating combination, and local defect in IL-10 production in this abortion-prone combination is corrected by in vivo injection of IFN-r. Journal of Immunology 154 4261-4268.

Chaouat G, Cayol V, Mairovitz V \& Dubanchet S 1999 Localization of the Th2 cytokines IL-3, IL-4, IL-10 at the fetomaternal interface during human and murine pregnancy and lack of requirement for Fas/Fas ligand interaction for a successful allogeneic pregnancy. American Journal of Reproductive Immunology 42 1-13.

Chen T, Guo J, Yang M, Han C, Zhang M, Chen W, Liu Q, Wang J \& Cao X 2004 Cyclosporin A impairs dendritic cell migration by regulating chemokine receptor expression and inhibiting cyclooxygenase-2 expression. Blood 103 413-421.

Collins AV, Brodie DW, Gilbert RJC, laboni A, Manso-Sancho R, Walse B, Stuart DI, van der Merwe PA \& Davis SJ 2002 The interaction properties of costimulatory molecules revisited. Immunity 17 201-210.

Das-Bradoo S, Ricke RM \& Bielinsky AK 2006 Interaction between PCNA and diubiquitinated $\mathrm{Mcm} 10$ is essential for cell growth in budding yeast. Molecular and Cellular Biology 26 4806-4817.

Du MR, Dong L, Zhou WH, Yan FT \& Li DJ 2007 Improves pregnant outcome by promoting functions of trophoblasts and inducing maternal tolerance to the allogeneic fetus. Biology of Reproduction 76 906-914.

Emmel EA, Werweij CL, Durand DB, Higgins KM, Lacy E \& Crabtree GR 1989 Cyclosporin A specifically inhibits function of nuclear proteins involved in T cell activation. Science 246 1617-1620.

Gardner L \& Moffett A 2003 Dendritic cells in the human decidua. Biology of Reproduction 69 1438-1446.

Gorczynski RM, Hadidi S, Yu G \& Clark DA 2002 The same immunoregulatory molecules contribute to successful pregnancy and transplantation. American Journal of Reproductive Immunology $\mathbf{4 8}$ $18-26$.

Greene JL, Leytze GM, Emswiler J, Peach R, Bajorath J, Cosand W \& Linsley PS 1996 Covalent dimerization of CD28/CTLA-4 and oligomerization of CD80/CD86 regulate $\mathrm{T}$ cell costimulatory interactions. Journal of Biological Chemistry 271 26762-26771.

Greer IA 2003 Thrombophilia: implications for pregnancy outcome. Thrombosis Research 109 73-81.

de Groot CJ, O'Brien TJ \& Taylor RN 1996 Biochemical evidence of impaired trophoblastic invasion of decidual stroma in women destined to have preeclampsia. American Journal of Obstetrics and Gynecology 175 24-29.

Guinan EC, Gribben JG, Boussiotis VA, Freeman GJ \& Nadler LM 1994 Pivotal role of the B7:CD28 pathway in transplantation tolerance and tumor immunity. Blood 84 3261-3282.

Hall BM, Pearce NW, Gurley KE \& Dorsch SE 1990 Specific unresponsiveness in rats with prolonged cardiac allograft survival after treatment with cyclosporine. III. Further characterization of the CD4+ suppressor cell and its mechanism of action. Journal of Experimental Medicine $\mathbf{1 7 1}$ 141-157.

Heikkinen J, Mottonen M, Alanen A \& Lassila O 2004 Phenotypic characterization of regulatory $\mathrm{T}$ cells in the human decidua. Clinical and Experimental Immunology 136 373-378.

Higuma-Myojo S, Sasaki Y, Miyazaki S, Sakai M, Siozaki A, Miwa N \& Saito S 2005 Cytokine profile of natural killer cells in early human pregnancy. American Journal of Reproductive Immunology 54 21-29.

Hill JA, Polgar K \& Anderson DJ 1995 T-helper1-type immunity to trophoblast in women with recurrent spontaneous abortion. Journal of the American Medical Association 273 1933-1936.

Hustin J, Jauniaux E \& Schaaps JP 1990 Histological study of the maternoembryonic interface in spontaneous abortion. Placenta 11 477-486.

Jameson SC \& Bevan MJ 1995 T cell receptor antagonists and partial agonists. Immunity 2 1-11.

Jin LP, Li DJ, Zhang JP, Wang MY, Zhu XY, Zhu Y, Meng Y \& Yuan MM 2004 Adoptive transfer of paternal antigen-hyporesponsive $T$ cells induces maternal tolerance to the allogeneic fetus in abortion-prone matings. Journal of Immunology 173 3612-3619. 
Jirapongsananuruk O \& Leung DY 1999 The modulation of B7.2 and B7.1 on B cells by immunosuppressive agents. Clinical and Experimental Immunology 118 1-8.

Jokhi PP, King A \& Loke YW 1994a Production of granulocyte-macrophage colony-stimulating factor by human trophoblast cells and by decidual large granular lymphocytes. Human Reproduction 9 1660-1669.

Jokhi PP, King A, Sharkey AM, Smith SK \& Loke YW $1994 b$ Screening for cytokine messenger ribonucleic acids in purified human decidual lymphocyte populations by the reverse-transcriptase polymerase chain reaction. Journal of Immunology 153 4427-4435.

June CH, Bluestone JA, Nadler LM \& Thompson CB 1994 The B7 and CD28 receptor families. Immunology Today 15 321-331.

Kadyrov M, Kingdom JC \& Huppertz B 2006 Divergent trophoblast invasion and apoptosis in placental bed spiral arteries from pregnancies complicated by maternal anemia and early-onset preeclampsia/intrauterine growth restriction. American Journal of Obstetrics and Gynecology 194 557-563.

Kammerer U, Schoppet M, McLellan AD, Kapp M, Huppertz HI, Kampgen E \& Dietl J 2000 Human decidua contains potent immunostimulatory CD83(+) dendritic cells. American Journal of Pathology 157 159-169.

Kammerer U, Eggert AO, Kapp M, McLellan AD, Geijtenbeek TB, Dietl J, van Kooyk Y \& Kampgen E 2003 Unique appearance of proliferating antigen-presenting cells expressing DC-SIGN (CD209) in the decidua of early human pregnancy. American Journal of Pathology 162 887-896.

Kanai-Azuma M, Kanai Y, Kurohmaru M, Sakai S \& Hayashi Y 1993 Insulinlike growth factor (IGF)-I stimulates proliferation and migration of mouse ectoplacental cone cells, while IGF-II transforms them into trophoblastic giant cells in vitro. Biology of Reproduction 48 252-261.

Kiger N, Chaouat G, Kolb JP, Wegmann TG \& Guenet JL 1985 Immunogenetic studies of spontaneous abortion in mice. Preimmunization of females with allogeneic cells. Journal of Immunology 134 2966-2970.

Kingsley CL, Karim M, Bushell AR \& Wood K 2002 CD25+CD4+ regulatory $\mathrm{T}$ cells prevent graft rejection: CTLA4 - and IL-10-dependent immunoregulation of alloresponses. Journal of Immunology $\mathbf{1 6 8}$ 1080-1086.

Laird SM, Tuckerman EM, Cork BA, Linjawi S, Blakemore AI \& Li TC 2003 A review of immune cells and molecules in women with recurrent miscarriage. Human Reproduction Update 9 163-174.

Lee JI, Ganster RW, Geller DA, Burckart GJ, Thomson AW \& Lu L 1999 Cyclosporin A inhibits the expression of costimulatory molecules on in vitro-generated dendritic cells: association with reduced nuclear translocation of nuclear factor kappa B. Transplantation 68 1255-1263.

Li XC, Zand MS, Li Y, Zheng XX \& Strom TB 1998 On histocompatibility barriers, Th1 to Th2 immune deviation, and the nature of the allograft responses. Journal of Immunology 161 241-247.

Linsley PS, Brady W, Grosmaire L, Aruffo A, Damle NK \& Ledbetter JA 1991 Binding of the B cell activation antigen B7 to CD28 costimulates T cell proliferation and interleukin 2 mRNA accumulation. Journal of Experimental Medicine 173 721-730.

Liu J, Sakane T \& Tsunematsu T 1992 The effects of FK-506 and cyclosporin A on the proliferation of PHA-stimulated T cells in response to IL-2, IL-4 or IL-6. International Archives of Allergy and Immunology 198 293-298.

Matthiesen L, Berg G, Ernerudh J, Ekerfelt C, Jonsson Y \& Sharma S 2005 Immunology of preeclampsia. Chemical Immunology and Allergy 89 49-61.

van der Meer A, Lukassen HG, van Lierop MJ, Wijnands F, Mosselman S, Braat DD \& Joosten I 2004 Membrane-bound HLA-G activates proliferation and interferon-gamma production by uterine natural killer cells. Molecular Human Reproduction 10 189-195.

van der Meer A, Lukassen HG, van Cranenbroek B, Weiss EH, Braat DD, van Lierop MJ \& Joosten I 2007 Soluble HLA-G promotes Th1-type cytokine production by cytokine-activated uterine and peripheral natural killer cells. Molecular Human Reproduction 13 123-133.

Mehrotra PK 1988 Ultrastructure of mouse ectoplacental cone cells. Biological Structures and Morphogenesis 1 63-68.

van der Merwe PA \& Davis SJ 2003 Molecular interactions mediating T cell antigen recognition. Annual Review of Immunology 21 659-684. van der Merwe PA, Bodian DL, Daenke S, Linsley P \& Davis SJ 1997 CD80(B7-1) binds both CD28 and CTLA-4 with a low affinity and very fast kinetics. Journal of Experimental Medicine 185 393-403.

Muntener M \& Hsu YC 1977 Development of trophoblast and placenta in the mouse. Acta Anatomica 98 241-252.

Nelson PA, Akselband Y, Kawamura A, Su M, Tung RD, Rich DH, Kishore V, Rosborough SL, DeCenzo MT \& Livingston DJ 1993 Immunosuppressive activity of [MeBm2t] 1-, D-diaminobutyryl-8-, and D-diaminopropyl-8cyclosporin analogues correlates with inhibition of calcineurin phosphatase activity. Journal of Immunology 150 2139-2147.

Olivares EG, Munoz R, Tejerizo G, Montes MJ, Gomez-Molina F \& AbadiaMolina AC 2002 Decidual lymphocytes of human spontaneous abortions induce apoptosis but not necrosis in JEG-3 extravillous trophoblast cells. Biology of Reproduction 67 1211-1217.

Peach RJ, Bajorath J, Brady W, Leytze G, Greene J, Naemura J, Bajorath J \& Linsley PS 1994 Complementarity determining region 1 (CDR1)- and CDR3-analogous regions in CTLA-4 and CD28 determine the binding to B7-1. Journal of Experimental Medicine 180 2049-2058.

Petroff MG, Chen L, Phillips TA, Azzola D, Sedlmayr P \& Hunt JS 2003 B7 family molecules are favorably positioned at the human materno-fetal interface. Biology of Reproduction 68 1496-1504.

Piccinni MP 2002 T-cell cytokines in pregnancy. American Journal of Reproductive Immunology 47 289-294.

Poggi A \& Zocchi MR 2005 Cyclosporin A regulates human NK cell apoptosis induced by soluble HLA-I or by target cells. Autoimmunity Reviews 4 532-536.

Qumsiyeh MB, Kim KR, Ahmed MN \& Bradford W 2000 Cytogenetics and mechanisms of spontaneous abortions: increased apoptosis and decreased cell proliferation in chromosomally abnormal villi. Cytogenetics and Cell Genetics 88 230-235.

Rieger L, Honig A, Sutterlin M, Kapp M, Dietl J, Ruck P \& Kammerer U 2004 Antigen-presenting cells in human endometrium during the menstrual cycle compared to early pregnancy. Journal of the Society for Gynecologic Investigation 11 488-493.

Saito S 2000 Cytokine network at the feto-maternal interface. Journal of Reproductive Immunology 47 87-103.

Saito S, Nishikawa K, Morii T, Enomoto M, Narita N, Motoyoshi K \& Ichijo M 1993 Cytokine production by CD16-CD56bright natural killer cells in the human early pregnancy decidua. International Immunology 5 559-563.

Saito S, Sasaki Y \& Sakai M 2005 CD4(+) CD25 high regulatory T cells in human pregnancy. Journal of Reproductive Immunology 65 111-120.

Sakaguchi S 2004 Naturally arising CD4+ regulatory T cells for immunologic self-tolerance and negative control of immune responses. Annual Review of Immunology 22 531-562.

Sakaguchi S, Sakaguchi N, Asano M, Itoh M \& Toda M 1995 Immunological self-tolerance maintained by activated T-cells expressing IL-2 receptor a-chains (CD25). Breakdown of a single mechanism of selftolerance causes various auto-immune diseases. Journal of Immunology 155 1151-1164.

Salama AD, Najafian N, Clarkson MR, Harmon WE \& Sayegh MH 2003 Regulatory CD25+T cells in human kidney transplant recipients. Journal of the American Society of Nephrology 14 1643-1651.

Sauma D, Fierro A, Mora JR, Lennon-Dumenil AM, Bono MR, Rosemblatt M \& Morales J 2003 Cyclosporine preconditions dendritic cells during differentiation and reduces IL-2 and IL-12 production following activation: a potential tolerogenic effect. Transplantation Proceedings 35 2515-2517.

Sayegh MH \& Turka LA 1995 T cell costimulatory pathways: promising novel targets for immunosuppression and tolerance induction. Journal of the American Society of Nephrology 6 1143-1150.

Sketris I, Yatscoff R, Keown P, Canafax DM, First MR, Holt DW, Schroeder TJ \& Wright M 1995 Optimizing the use of cyclosporine in renal transplantation. Clinical Biochemistry 28 195-211.

Staun-Ram E \& Shalev E 2005 Human trophoblast function during the implantation process. Reproductive Biology and Endocrinology 356.

Sykulev Y, Cohen RJ \& Eisen HN 1995 The law of mass action governs antigen-stimulated cytolytic activity of CD8 + cytotoxic T lymphocytes. PNAS 92 11990-11992.

Takahashi T, Tagami T, Yamazaki S, Uede T, Shimizu J, Sakaguchi N, Mak TW \& Sakaguchi S 2000 Immunologic self-tolernace maintained by 
$\mathrm{CD} 25(+) \mathrm{CD} 4(+)$ regulatory $\mathrm{T}$ cells constitutively expressing cytotoxic $\mathrm{T}$ lymphocyte-associated antigen 4. Journal of Experimental Medicine 192 303-310.

Thompson CB, Lindsten T, Ledbetter JA, Kunkel SL, Young HA, Emerson SG, Leiden JM \& June $\mathbf{C H} 1989$ CD28 activation pathway regulates the production of multiple T-cell-derived lymphokines/cytokines. PNAS 86 1333-1337.

Thornton AM \& Shevach EM 1998 CD4+CD25+ immunoregulatory T cells suppress polyclonal $\mathrm{T}$ cell activation in vitro by inhibiting interleukin 2 production. Journal of Experimental Medicine 188 287-296.

Tivol EA, Borriello F, Schweitzer AN, Lynch WP, Bluestone JA \& Sharpe AH 1995 Loss of CTLA-4 leads to massive lymphoproliferation and fatal multiorgan tissue destruction, revealing a critical negative regulatory role of CTLA-4. Immunity 3 541-547.

Trundley A \& Moffett A 2004 Human uterine leukocytes and pregnancy. Tissue Antigens 63 1-12.

Valitutti S, Müller S, Dessing M \& Lanzavecchia A 1996 Different responses are elicited in cytotoxic T lymphocytes by different levels of T cell receptor occupancy. Journal of Experimental Medicine 183 1917-1921.

Vassiliadis S, Tsoukatos D \& Athanassakis I 1994 Interferon-induced class II expression at the spongiotrophoblastic zone of the murine placenta is linked to fetal rejection and developmental abnormalities. Acta Physiologica Scandinavica 151 485-495.

Veenstra van Nieuwenhoven AL, Heineman MJ \& Faas MM 2003 The immunology of successful pregnancy. Human Reproduction Update 9 347-357.

Viola A \& Lanzavecchia A 1996 T cell activation determined by T cell receptor number and tunable thresholds. Science 273 104-106.

Waldmann H, Graca L, Cobbold S, Adams E, Tone M \& Tone Y 2004 Regulatory T cells and organ transplantation. Seminars in Immunology 16 119-126.

Walunas TL, Lenschow DJ, Bakker CY, Linsley PS, Freeman GJ, Green JM, Thompson CB \& Bluestone JA 1994 CTLA-4, can function as a negative regulator of $\mathrm{T}$ cell activation. Immunity $\mathbf{1}$ 405-413.

Wasowska BA, Zheng XX, Strom TB \& Kupieck-Weglinski JW 2001 Adjunctive rapamycin and CsA treatment inhibits monocyte/macrophage associated cytokines/chemokines in sensitized cardiac graft recipients. Transplantation 71 1179-1183.

Waterhouse P, Penninger JM, Timms E, Wakeham A, Shahinian A, Lee KP, Thompson CB, Griesser H \& Mak TW 1995 Lymphoproliferative disorders with early lethality in mice deficient in Ctla-4. Science $\mathbf{2 7 0}$ 985-988.

Wegmann TG, Lin H, Guilbert L \& Mossmann TR 1993 Biodirectional cytokine interactions in the materno-fetal relationship: is successful pregnancy a Th2 phenomenon? Immunology Today 14 $353-356$.
Welsh AO \& Enders AC 1987 Trophoblast-decidual cell interaction and establishment of maternal blood circulation in the parietal yolk sac placenta of the rat. Anatomical Record 217 203-219.

Wilczynski JR 2006 Immunological analogy between allograft rejection, recurrent abortion and pre-eclampsia - the same basic mechanism? Human Immunology 67 492-511.

Wood KJ \& Sakaguchi S 2003 Regulatory T cells in transplantation tolerance. Nature Reviews. Immunology 3 199-210.

Wu X, Li DJ, Yuan MM, Zhu Y \& Wang MY 2004 The expression of CXCR4/CXCL12 in first-trimester human trophoblast cells. Biology of Reproduction 70 1877-1885.

Yamada H, Morikawa M, Kato EH, Shimada S, Kobashi G \& Minakami H 2003 Pre-conceptional natural killer cell activity and percentage as predictors of biochemical pregnancy and spontaneous abortion with normal chromosome karyotype. American Journal of Reproductive Immunology 50 351-354.

Yan F, Li D, Sun X, Zhu Y, Wang M, Meng Y \& Yu J 2002a Effect of cyclosporin $\mathrm{A}$ on the growth of human first trimester cytotrophoblasts in vitro. Zhonghua Fu Chan Ke Za Zhi 37 74-76.

Yan FT, Li DJ, Sun XX, Zhu XY, Zhu Y, Meng Y \& Yu J $2002 b$ Effect of cyclosporin $A$ on prognosis of the abortion-prone murine model. Zhongguo Mian Yi Xue Za Zhi 18 711-712.

Zelenika D, Adams E, Humm S, Lin CY, Waldmann H \& Cobbold SP 2001 The role of $\mathrm{CD} 4+\mathrm{T}$-cell subsets in determining transplantation rejection or tolerance. Immunological Reviews 182 164-179.

Zenclussen AC $2005 \mathrm{CD} 4(+) \mathrm{CD} 25+\mathrm{T}$ regulatory cells in murine pregnancy. Journal of Reproductive Immunology 65 101-110.

Zenclussen AC, Gerlof K, Zenclussen ML, Ritschel S, Zambon Bertoja A, Fest S, Hontsu S, Ueha S, Matsushima K, Leber J et al. 2006 Regulatory T cells induce a privileged tolerant microenvironment at the fetal-maternal interface. European Journal of Immunology 36 82-94.

Zhou WH, Du MR, Dong L, Zhu XY, He YY \& Li DJ 2007 Modulation of cyclosporin a on the expression of MMP-9 and MMP-2 of the first-trimester human trophoblast cells. Fen Zi Xi Bao Sheng Wu Xue Bao 40 62-68.

Zhu XY, Zhou YH, Wang MY, Jin LP, Yuan MM \& Li DJ 2005 Blockade of CD86 signaling facilitates a Th2 bias at the materno-fetal interface and expands peripheral $C D 4+C D 25+$ regulatory $T$ cells to rescue the abortion-prone fetuses. Biology of Reproduction 72 338-345.

Received 6 February 2007

First decision 6 March 2007

Revised manuscript received 16 October 2007

Accepted 5 November 2007 